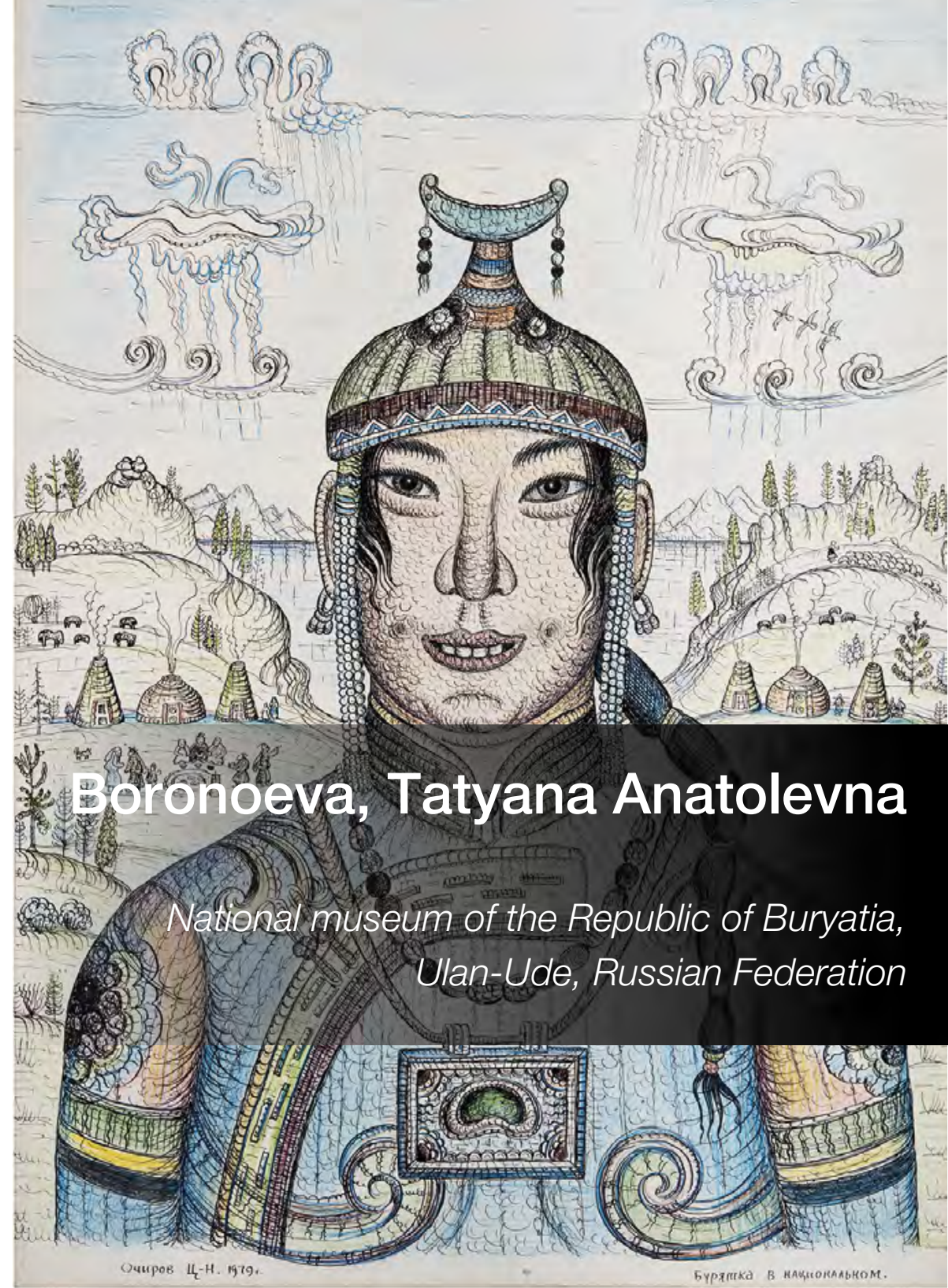

Очиров «- H.
Бороноева Татьяна Анатольевна

Национальный музей Республики Бурятия,

г. Улан-Удэ, Российская Федерация

\section{КАРТИНА МИРА В ГРАФИКЕ \\ БУРЯТСКОГО ХУДОЖНИКА \\ Ц.-Н. ОЧИРОВА}

THE PICTURE OF THE WORLD

IN THE GRAPHIC ART OF THE BURYAT PAINTER TSYREN-NAMZHIL OCHIROV

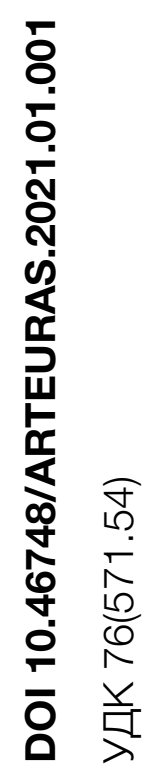


БЛАГОДАРНОСТИ: Автор выражает благодарность дочери художника Розе Цыреновне Очировой и художнику Александру Морисовичу Москвитину за прекрасные воспоминания об отце и друге.

ACKNOWLEDGMENTS:The author is grateful to the artist's daughter Rosa Ts. Ochirova and the artist Alexander M. Moskvitin for wonderful memories of Tsyren-Namzhil Ochirov.

\section{АННОТАЦИЯ}

Статья посвящена творчеству выдающегося художника Цырен-Намжила Очирова (19201987), чей феномен заключается в своеобразном синтезе народной философиии, «наивной» простоты графического изображения и возвышенной любви к своей малой родине «тоонто нютаг». Факты биографии буддийского самодеятельного художника, близость его творчества буддийскому наследию установлены в исследованиях 1980-1990-х годов, а в 2019 году впервые опубликовано около 150 произведений Очирова из личных архивов семьи. В настоящей статье представлен впервые проведенный анализ графического наследия Ц.-Н. Очирова на основе материалов из фондов Национального музея Республики Бурятия, а также частной коллекции из семьи художника. Определены истоки творчества мастера, связи с традицией буддийской графики, бурятским мировоззрением, стилем «буряад зураг». Автор впервые приводит материалы личных бесед с членами семьи и коллегами художника. В исследовании использован комплекс искусствоведческих методов и элементы историко-описательного метода.

\section{КЛЮЧЕВЫЕ СЛОВА:}

Грасикка; Цырен-Намжил Очиров; картина мира; традиционная культура; буддийские традиции; буряад зураг.

\section{ABSTRACT}

The article deals with the artistic heritage of the outstanding Buryat artist Tsyren-Namzhil Ochirov (1920-1987), whose artistic phenomenon is based on the specific combination of the life philosophy, "naive" simplicity of depiction and the poetic love to his motherland called the Tonto Nyutag by the Buryat people. The public interest to his art was raised during the artist's lifetime. In the early 1970s, several articles dedicated to his art were released in local newspapers. His unique artistic manner was studied by a group of young amateur artists who were members of the Republican Center of Amateur and Folk Arts in Ulan-Ude.

Serious research work on his rich artistic heritage conducted by art critics and scholars started after his death. In the late 1980s and the early 1990s Svetlana Tsybiktarova, the art critic and the science assistant of the Khangalov Historical Museum in Ulan-Ude, together with her elder colleague from Leningrad Natalya lofan, released the article entitled "The artist from Mogsokhon". The name of Tsyren-Namzhil Ochirov was introduced to the world of art experts for the very first time. The authors revealed the correlation between his art and the traditional Buddhist painting. Tatyana Boronoeva in her monography "Graphic art in Buryatia" made a partial analysis of Tsyren-Namzhil Ochirov's art in the chapter "Art of self-taught painters and the problem of ethnicity in the Buryat graphics". Larisa Nikolaeva in the article entitled "The art system of the Buryat amateur painter Tsyren-Namzhil Ochirov (1920-1987)" shared with readers some interesting facts from his life. In her article, she also underlined some similar features of the traditional Buddhist painting in his art. In 2019, the year prior to the 100-th anniversary of the artist, the family of TsyrenNamzhil Ochirov published an album of his graphic works. The content of the album was compiled by his granddaughter $\mathrm{S}$. Tarnueva. One hundred and fifty drawings were selected from the family archive and were introduced to the wide public. The rich art heritage of Tsyren-Namzhil Ochirov numbering about five hundred works includes thirty manuscripts and wooden items of the decorative and applied art.

The author of the current article makes an analysis of the graphic works of Tsyren-Namzhil Ochirov from the funds of the National Museum of the Republic of Buryatia and from the private collection of the artist's family. Of a great importance for the author of the article is the definition of his art's origin, which is, on the one hand, derived from the traditional Buddhist painting, and, "the Buryat Zurag" on the other. The latter is the painting created in a specific artistic manner that reflects the world perception of the Buryat people. For the better description of the topic, the author publishes the conversations with the daughter of the artist Roza Tsyrenovna, with the painter Alexander Moskvitin, his close friend and the speech of the Buryat artist Zandan Dugarov at the event Round Table dedicated to Tsyren-Namzhil Ochirov's art in 2016.

The author of the article uses artistic methods and elements of the historic approach as the complex tool in her research work.

\section{KEYWORDS:}

Tsyren-Namzhil Ochirov; graphic art; picture of the world; traditional culture; Buddhist traditions; Buryad Zurag; Buryat painting. 


\section{Введение}

Изучение творчества Цырен-Намжила Очирова началось при жизни мастера, в начале 1970-х годов в секции самодеятельных художников при Республиканском центре народного творчества в г. Улан-Удэ. Результатом стали в основном газетные публикации. Настоящие исследования начались уже после смерти художника. Огромную работу по сбору информации и изучению творческого наследия Очирова в конце 1980-х — начале 1990-х гг. провела искусствовед, сотрудник Музея истории Бурятии Светлана Цыбыктарова [7]. Ее статья в соавторстве с Н. Иофан «Художник из Могсохона» позволила ввести в научный оборот имя художника, также впервые была обозначена близость художника к буддийскому наследию. В монографии «Графика Бурятии» Т.А. Бороноева частично исследует творчество Очирова в разделе «Искусство самоучек и проблема этнической изобразительности в графике Бурятии» [2]. В статье Л.Ю. Николаевой «Художественная система бурятского самодеятельного художника Цырен-Намжила Очирова (1920-1987)» приводятся интересные факты из жизни художника. Анализируя его творчество, Николаева приходит к выводу о близости Очирова к буддийской художественной системе [9, с. 259]. В 2019 году в преддверии 100-летнего юбилея художника семья издала небольшой альбом с работами художника, автор-составитель С. Тарнуева (внучка художника) [12]. Здесь впервые опубликованы работы Очирова из личных архивов семьи - это 150 рисунков. Все наследие Очирова обширно — около 500 работ, включая 30 рукописных книг и предметы декоративно-прикладного искусства из дерева.

В настоящей статье представлен впервые проведенный анализ графического наследия Ц.-Н. Очирова на основе материалов из фондов Национального музея Республики Бурятия, а также частной коллекции из семьи художника. С целью определить истоки творчества художника, отражение мировоззрения в системе изобразительных средств к исследованию привлечены материалы личных бесед с дочерью художника Цырен-Намжила Очирова Розой Цыреновной [5], с художником Александром Москвитиным [6], личным другом Очирова, а также выступление на круглом столе в 2016 году Зандана Дугарова, народного художника Республики Бурятия [3]. В исследовании использовался комплекс искусствоведческих методов и элементы историкоописательного метода.

\section{Обсуждение}

Во второй половине 1980-х годов, как мы отмечали ранее, «на фоне изменений в политической и духовной жизни страны ощущается потребность в глубоком осмыслении национальной художественной традиции, в ее истоках и перспективах развития национальной школы. Этим тенденциям глубоко созвучной оказалась графика талантливых мастеров-самоучек Л. Доржиева и Ц.-Н. Очирова, творчество которых органично связано с мифопоэтической, фольклорной традицией народного искусства» [2, с. 66]. Определим далее истоки творчества уникального мастера Ц.-Н. Очирова.

Цырен-Намжил Очиров родился 4 февраля 1920 года в местности Сойсон, в родовом стойбище, что в полутора километрах западнее улуса. Окончив Кижингинскую школу, поступил в Агинское педучилище, а завершил учебу в УланУдэнском педагогическом училище. В начале 1940 года его призвали в ряды Красной Армии. Отслужив почти семь лет, участник войны с Японией, радист второго класса Цырен-Намжил Очиров более десяти лет учительствовал в селах. Он хорошо знал историю малой родины, этнографию, устный фольклор. Писал познавательные статьи о своем крае, рассказы, зарисовки о тружениках совхоза, юмористические сценки, стихи. Как вспоминает его земляк Н. Галданов, «летом 1953 года Дом офицеров провел шахматный турнир на первенство гарнизона. Из семи военных городков собрались семнадцать шахматистов, в том числе и Очиров. В упорной борьбе он занял пятое место» [12, с. 27]. В своем родном селе Могсохон Очиров организовал краеведческий музей, который носит его имя. Пожалуй, самым значимым, не имеющим цены экспонатом в музее считается дневник «Родословное древо местныХ», составленный Ц.-Н. Очировым. Его автор в течение 20 лет обходил все дворы села, скрупулезно восстанавливая родовую ветвь каждой семьи.

Р.Ц. Очирова так говорит о его творчестве: «Отец очень много думал, в голове у него рождались идеи. Потом он садился и рисовал. Вначале как бы черновик. Привозил из города ватманы, карандаши, тушь. Плодотворно работал 10-15 лет. Все говорят, что он родился не в свое время. Его работы осмысленные. Для них характерны наивность и легкий юмор. В 1964 году он написал письмо в "Учительскую газету", в котором писал о падении нравственности и необходимости преподавания буддийской этики в школах. Это письмо вернулось из Москвы в Бурятию, и здесь его [Очирова] решили исключить из партии, а также уволили с работы. Отец был сильным человеком, он сильно не унывал. Когда отца исключали из партии, он сидел и играл на мандолине. Он общался с кругом знаменитого тантриста Б. Дандарона. В то время за ними наблюдали люди из органов» [5]. Очиров много работал над собой, читал буддийскую литературу, изучал языки. С этого времени он полностью погрузился в творчество.

Александр Москвитин, художник и друг Ц.-Н. Очирова, вспоминает: «Я впервые увидел его на встрече, которую организовал А. Чайковский, сотрудник Центра народного творчества. Зашел 
высокий мужчина - в руках свернутый рулон, губа оттопырена, очень основательный и мощный. Он развернул и показал свои работы. И я понял, что это очень талантливо. Мы сразу понравились друг другу. Наша дружба продолжалась долгие годы. Мы решили работать, я советовал ему, как работать, какие использовать материалы. Сначала у него работы были другие, линия четкая и ровная ("Денсема", "Встреча", 1975). Позже он начинает вводить пейзаж, и линия становится сложной и витиеватой. Я часто приезжал к нему в Могсохон, мы подолгу беседовали, он показывал окрестности и свои любимые места. А когда он приезжал в город, всегда останавливался у моих родителей на ул. Шмидта в городе Улан-Удэ. Я всегда знал, что он станет выдающимся художником. Он очень близок к народному искусству. В то же время его творчество восходит к глубинным истокам древнего зооморфного стиля, характерного для кочевых народов» [6].

Цырен-Намжил Очиров учительствовал долгие годы. Но делом его жизни было не только преподавание школьных предметов. С самого начала он совмещал его с широкой просветительской деятельностью, неутомимо изучая не только бурят, но и эвенков, русских и другие народы, живущие на земле Бурятии.

Интерес к фольклору и этнографии пробудился у Очирова еще в годы учебы. Благодаря давнему увлечению историей, Ц.-Н. Очиров оказался хорошо подготовленным к избранной им деятельности народного просветителя, которая, без преувеличения, становится делом его жизни.

Просветительская деятельность, несомненно, сыграла большую роль в становлении Очировахудожника. Первый рисунок, не считая рабочих фольклорно-этнографических зарисовок, он сделал в 1960-е годы для своих публикаций в местной печати. Газеты «Кижингинская долина», «Буряад Унэн» во второй половине 1960-х годов постоянно помещали различные бурятские притчи, собранные Ц.-Н. Очировым, и, что еще важнее, в процессе обработки и систематизации собранных материалов он приступил к созданию прекрасно иллюстрированных рукописных книг, уже готовых к изданию. Очиров стал активным участником всесоюзных, международных выставок самодеятельных художников. К нему приходит известность. С 1977 по 1987 год Очирову шесть раз присуждались дипломы первой степени и золотые медали четырех советских и двух международных выставок в Лондоне и Берлине [7, с. 95]. Разносторонний жизненный опыт, широта взглядов и народная мудрость достойно и полно отражены в его рисунках. Очиров яркий представитель традиции «деревенского знаточества». Еще в XIX веке в бурятских селах всегда были свои грамотеи, которые занимались перепиской популярной буддийской литературы в основном нравоучительного характера. При желании и умении они сами же и являлись иллюстраторами текстов (таковы иллюстрации к известной книге «Повесть о Молон-тойне» начала $X X$ в.) [2, с. 95].

Картина мира художника дает возможность по-новому осмыслить сложную и во многом неоднозначную проблему этнической изобразительности в искусстве бурят в контексте национального и общечеловеческого. Собственно первый, уникальный в своем роде эксперимент по выявлению и сохранению особенностей мировосприятия в изобразительном творчестве северных народов был проведен в Ленинграде в 1920-1930-е гг. при Институте восточных языков. В студии на факультете северных народов (Севфак), которой руководил Л. Месс, подход к подопечным, еще сохранившим черты родового, по сути первобытного сознания, осуществлялся согласно теориям о специфике примитивного творчества (А.В. Бакушинский) [2, C. 94].

Интерес к северянам в ленинградской интеллигентской среде был очень велик. В Русском музее была устроена выставка, к которой был выпущен каталог с несколькими статьями, среди них следует выделить написанную Н. Пуниным - «Искусство примитива и современный рисунок». «Человек, - подчеркивал Пунин, - это человек-зверь, человек-камень, человек-дерево, человек-тайга». Созданное по этим неписаным правилам произведение венчается настоящей радостью, «которая бывает всегда, когда смотришь на произведения подлинного искусства» [8, с. 14]. Мастер создает радостный гимн небу, лесу, оленю, медведю, реке, своим предкам - всему Космосу!

Выявленные Пуниным такие черты примитива, как цельность, непосредственность, слитность с природой, связь с материалом, можно смело отнести к творчеству Ц.-Н. Очирова. Феномен мастера второй половины XX века связан, на наш взгляд, с двумя направлениями.

Во-первых, истоки его творчества - в самобытной школе традиционной бурятской графики, связанной с буддийским искусством. Здесь можно вспомнить о традиции изображений на иконах «Сансарын хурдэ». По легенде они восходят к самому Будде и являются отражением аллегорической картины мира согласно буддийскому учению о перерождениях и испытаниях, падающих на долю человека. Эти изображения, живописные или графические, помещались для знакомства с ними верующих. Однако наряду с каноническими сюжетами в иконе «Сансарын хурдэ» большое место отводилось изображению мира людей и животных. В этих порой наивных рисунках художник мог проявить всю свою наблюдательность, запечатлевая 
повседневную жизнь людей, их обычаи и нравы. Истоки жанровых композиций мастеров традиционной графики, таких как О. Будаев и Г. Эрдэнийн, связаны именно с этой «жизненной трактовкой бытовых сюжетов, обусловленных стихийным мировосприятием народа» [4, с. 115].

Очиров, не имея профессионального художественного образования, но будучи глубоко верующим буддистом, изучал буддийскую литературу, прекрасно знал историю Бурятии. Вспоминает его дочь Роза Цыреновна: «Отец очень много читал, особенно по философии Японии, Китая, свободно владел старомонгольским языком, учил английский и арабский. У отца была своя небольшая мастерская - домик во дворе, где он подолгу сидел, иногда оттуда доносился смех. Он очень продумывал композицию в голове, практически потом воплощал. Он ходил, продумывал и потом мог сесть и сразу написать» [5]. Н. Иофан и С. Цыбыктарова в своей статье «Художник из Могсохона» писали: «Принадлежность к традиционной культуре бурят с ее цельностью, прочностью и устойчивостью, уверенностью в справедливости многовековых идеалов помогла сформироваться замечательной творческой личности, верной долгу и убеждениям, воспитанным с детства, и в то же время открытой для восприятия жизни и культуры других народов. Традиционный изобразительный канон не только не ограничил, но, наоборот, открыл простор воображению художника - он населяет свои композиции живыми, одушевленными облаками и сопками, камнями и деревьями, и все они, активно взаимодействуя с героями и между собой, выступают полноправными участниками сюжетов. Вглядываясь, например, в изображение облаков, которые подобно драконам космогонического мифа собрались в небесах, или в огромные валуны, обступившие замершее горное озеро, убеждаешься, что это не просто традиционный декор. Содержательность образов в нашем представлении неодушевленной природы не вызывает сомнения. Как и в бурятской иконе, здесь своя, особенная система образного повествования, уходящая корнями в глубины бурятского мифа и фольклора. Они продолжают жить в воображении художника, соединившись с его знаниями подлинной истории. Творчество Цырена Очирова являет собой замечательный культурный феномен - это драгоценный сплав культур традиционного общества» [7, с. 95].

Сам художник в рукописной книге «Будда и его жизнь» (1964) пишет: «Тягостное расставание с Великим Учителем. . Все те дни сама природа, словно мать, застигнутая тяжелым горем, никла в смиренной тиши траура. Цветы клонились к земле, приумолкли птицы в лесах, не слышно было шелестение листьев на ветвях. Облака, плавно выраставшие с четырех сторон света, поднимались ввысь и смыкались, роняя мельчайшие капельки влаги. Они на иссиня-голубом фоне неба принимали причудливые очертания и оттенки, то походя на горы, леса и реки, то на дворцы и храмы» [10, с. 26]. Подобные этому описанию облака можно встретить в его работах. Они (облака), как отдельные герои, - то они похожи на орнаменты в виде рогов и барашков, то вдруг превращаются в радугу.

Во-вторых, творчество Очирова связано с направлением «буряад зураг» (близко к известному в монгольской живописи стилю «монгол зураг»). Характерные особенности этого стиля — плоскостность композиции, контрастность цветовых решений, преобладание графического начала, активное использование орнаментики. Наиболее яркий представитель этого направления в бурятском искусстве второй половины XX века - это Лубсан Доржиев. З.Д. Дугарова раскрывает содержательные основы стиля: «Если брать шире, то "буряад зураг" - это скорее художественная философия кочевого народа. "Буряад зураг" - это отражение внутреннего мира бурята (сэдьхэлсогоо багтааһан юртэмсэ). Сразу могу определить буряад зураг он многогранен и многосторонен. Для этого нужно вернуться к истории, к тем условиям формирования качеств бурят... Невстроенность в вертикаль какой-либо власти, при этом персональная ответственность перед Небом, Матерью-землей, своим родом и духами предков. Материальная культура неотделима от нематериальной, как и мир подземный, средний, небесный. Также материальную культуру невозможно разделять на отдельные составные, как то: ювелирное искусство смотреть в отрыве от деревянной и другой скульптуры, от живописи, от кузнечного мастерства. Зачастую дархан, в первую очередь подразумеваемый как кузнец, был в то же время и плотником, и ювелиром, и овчаром, и коневодом, и сказочником, и певцом, и костоправом, и еще много было других проявлений мастерства» [3]. Бурятский мир подвижен и динамичен, нет пустот и полостей, движение производится благодаря одному жесту или слову. Прекрасный пример - это молитвенный барабан, изменяющий мир в положительном направлении. Высказывание становится действием, символ теряет свою референтную функцию и приобретает перфомативную и выступает, как часть изменяющегося мира.

В коллекции Национального музея Республики Бурятия представлена небольшая, но очень выразительная коллекция графики Очирова (35 работ, тушь, перо). В 1991 году Светлана Цыбыктарова организовала первую персональную выставку его работ в Республиканском художественном музее имени Ц.С. Сампилова (сегодня музей входит в состав Национального музея Бурятии). После этой экспозиции часть работ была закуплена и вошла 


\section{1. Ц.-Н. Очиров.}

А.П. Чехов в Бурятии. 1900-е годы.

1982.

Бумага, тушь.

$53 \times 78$.

Коллекция семьи

художника

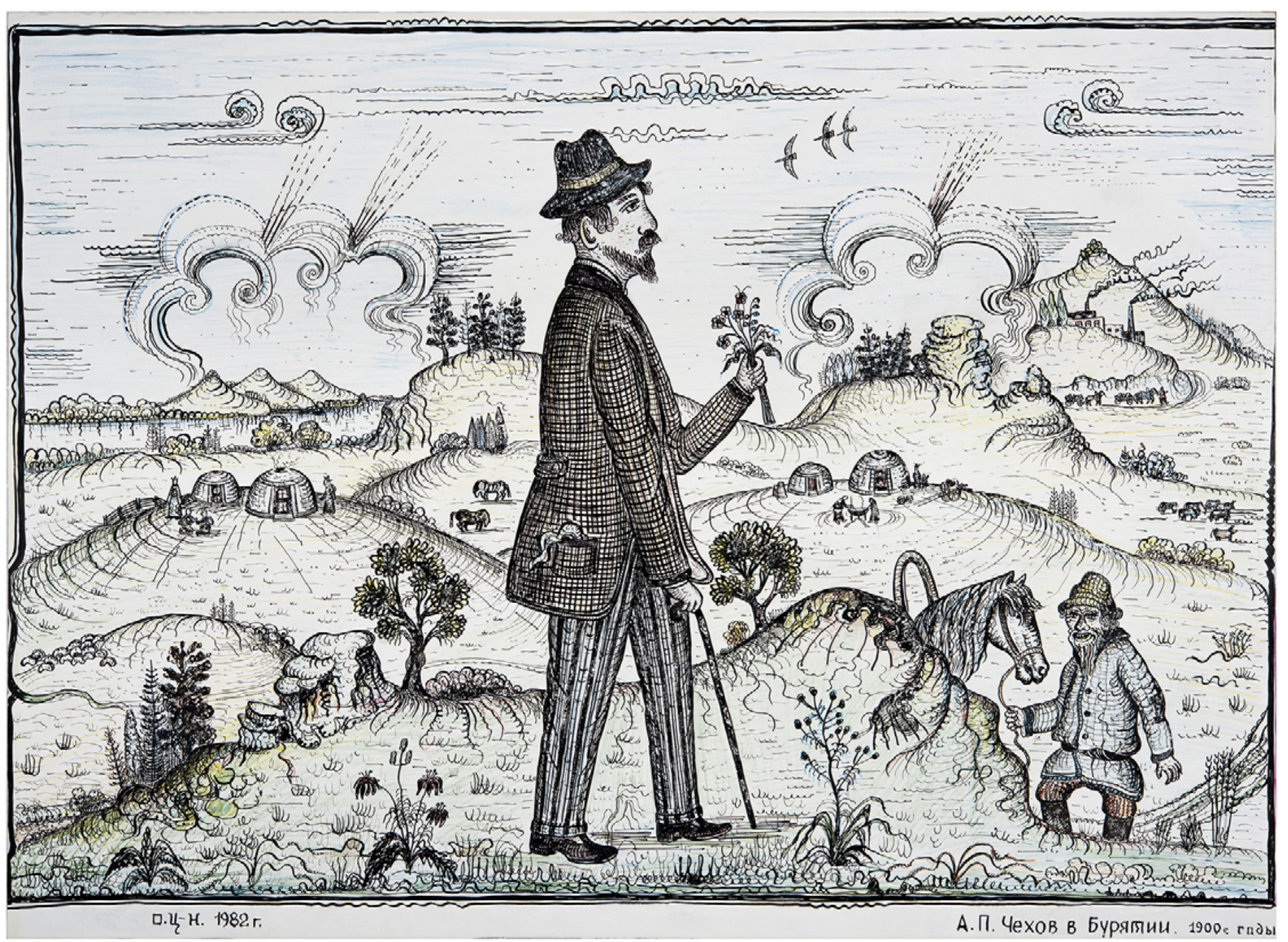

в коллекцию бурятского искусства, а 4 работы ранее были переданы автором выставки Музею истории Бурятии имени М. Хангалова (также в составе Национального музея Бурятии).

Собранный Очировым огромный краеведческий материал нашел отражение в тематике его серий, где главная роль отводится рисунку. Как отметила А.Ж. Бальжурова, «графическая манера Очирова необычайно индивидуальна, разнообразна и выразительна. Он словно всякий раз открывает для себя неисчерпаемые ресурсы техники рисунка тушью (пером и кистью). Очертания фигур, контуры изображений создаются особой вихрящейся линией» [1, с. 155].

Созданное художником за десятилетие (с конца 1970-х и вплоть до кончины в 1987 г.) может быть объединено в несколько главных композиций: «Бурятские традиции и обычаи», «Бурятские легенды и предания», иллюстрации улигеров «Аламжи Мэргэн», «Баабжи батор», «Гомбожап Цыбиков в Тибете», «Декабристы в Сибири», «А.П. Чехов в Бурятии. 1900-е годы» (рис. 1), серии «Бурятский участок БАМа», «Приезд агитбрига- ды в село», «Дружба навеки», «Аламжи мэргэн» и другие.

Начинал художник с одиночных рисунков на бытовые сюжеты, например «Денсема» (1980, бумага, тушь) или «Встреча» (1979, бумага, тушь). Размеры работ были небольшими, и видна была первоначальная проработка карандашом. Пейзаж как таковой отсутствовал, лишь тонко намечены облака. После общения с А. Москвитиным Цырен-Намжил Очиров обращается к более крупному формату. Непросто было с материалами, иногда рисовал на обороте обоев и клеенке. Если тушь удавалось найти, то с перьями и кистями возникали проблемы. По воспоминаниям дочери, отец сам делал перья и подбирал кисти. У него во дворе дома была своя маленькая мастерская, где он подолгу работал. Композиции становились более усложненными, многофигурными, линия обрела глубину и объем. Если посмотреть внимательно, то во всех его рисунках можно увидеть повторяющийся мотив встречи двух героев в центральной части композиции. Фигуры объемны и выразительны, изображены в профиль или анфас. Каждый герой для 

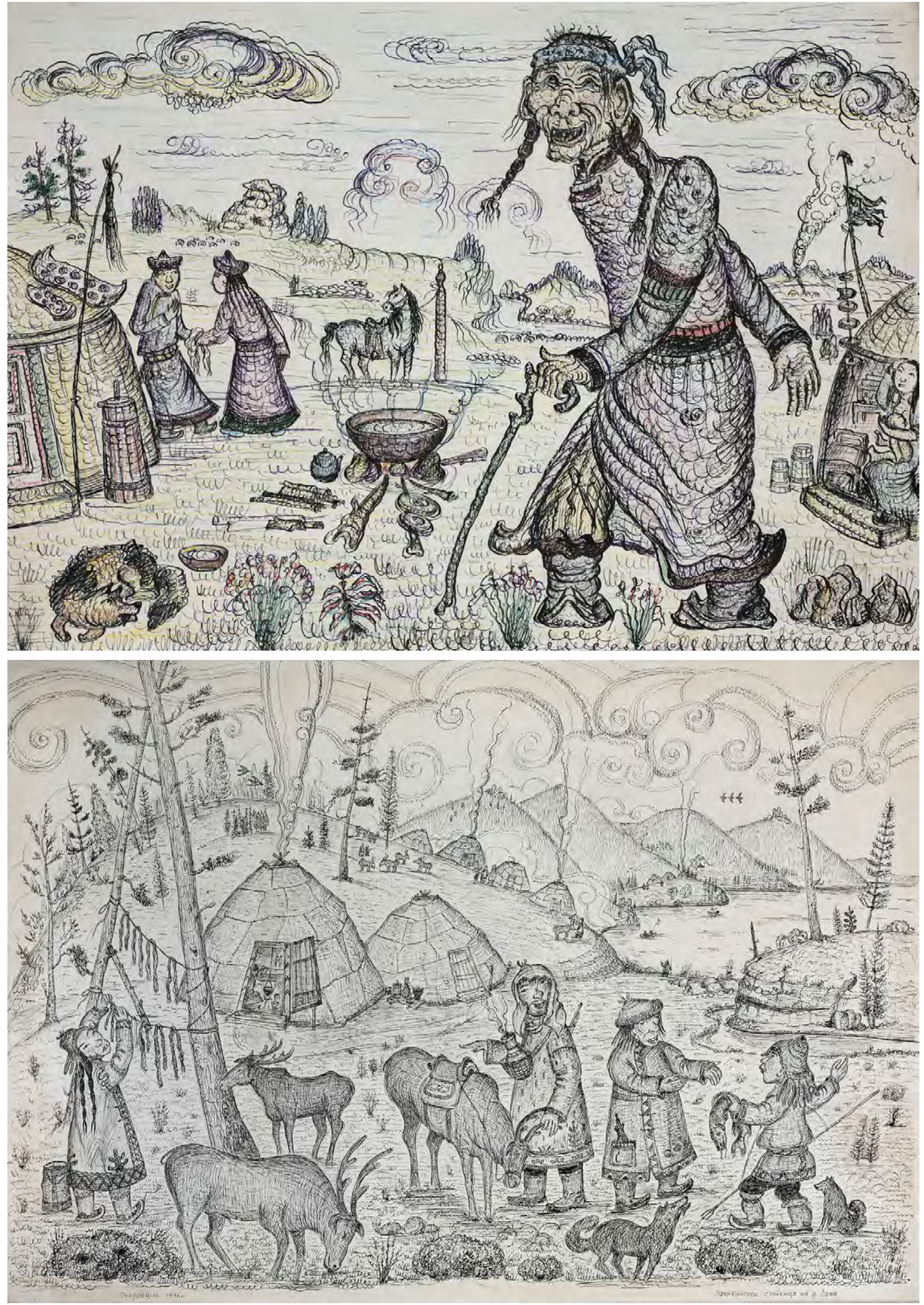

2. Ц.-Н. Очиров.

Бабушка,

устремившаяся в степь за скотом.

1980.

Бумага, тушь.

$34 \times 40$.

Национальный музей

Республики Бурятия

\section{З. Ц.-Н. Очиров.}

\section{Эвенкийское}

стойбище на реке Лене.

1976.

Бумага, тушь.

$58 \times 82$.

Коллекция семьи

художника 
4. Ц.-Н. Очиров.

\section{Бурятка}

в национальном.

1978.

Бумага, тушь.

$70 \times 52$.

Коллекция семьи

художника

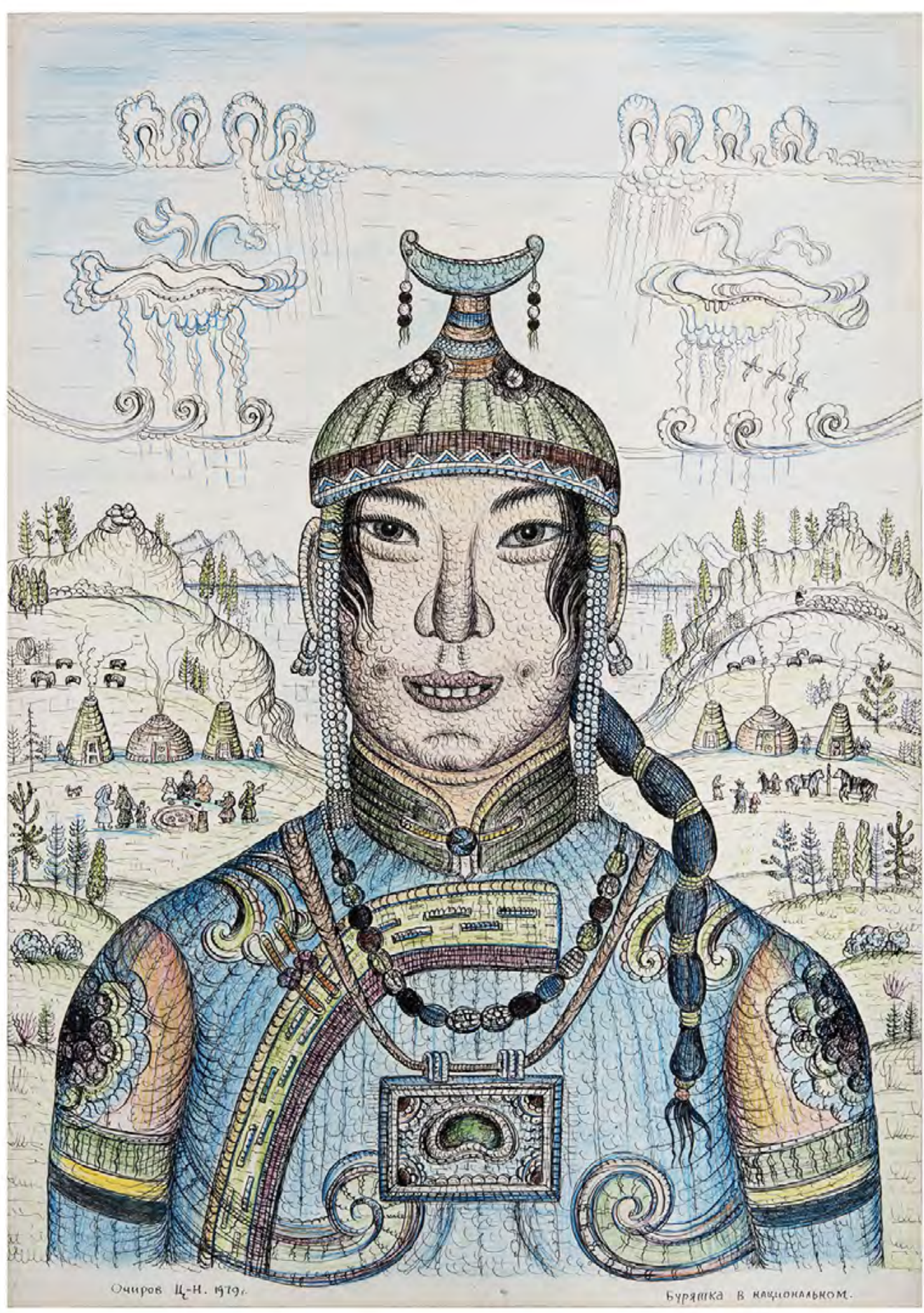

него важен, в лицах подчеркнута мимика, легкий гротеск. При этом есть ощущение абсолютной, почти детской непосредственности и искренней любви к своим персонажам. Для Очирова чрезвычайно важна тема родного очага (тоонто нютаг). Главными символами бурятской картины мира для Очирова становятся изображения юрты, коновязи, маслобойки, а главное очага. И это не просто этнограсические детали, а неотъемлемая часть космоса кочевника. Мир кочевой культуры органически связан с природой. Все герои Очирова «живут по законам Неба, сверяя с ним свои дела и помыслы и обеспечивая таким образом непрерывность ритма Вселенной, ее вечное существование» [11, с. 28].
Отсюда и дым очага из тооно (верх) юрты поднимается ввысь и сливается с облаками, создавая свои причудливые узоры и орнаменты, превращаясь то в радугу, то в мифических драконов. А солнце своими бесконечными лучами словно связывает все живущее на земле. Таковы его работы «У открытого очага» (1980), «Угощение вдовушки» (1978), «Бабушка, устремившаяся в степь за скотом» (1977; рис. 2), «Стойбище меркитов в Восточной Бурятии XII в.» (1986), «Эвенкийское стойбище на реке Лене» (1980; рис. 3), «Бурятка в национальном» (1979; рис. 4), «Разговор на вольном воздухе» (1981; рис. 5), «1702 г. Бурятская делегация на приеме у Петра |» (1984), «Гмибожап в Северном Тибете» (1986). 


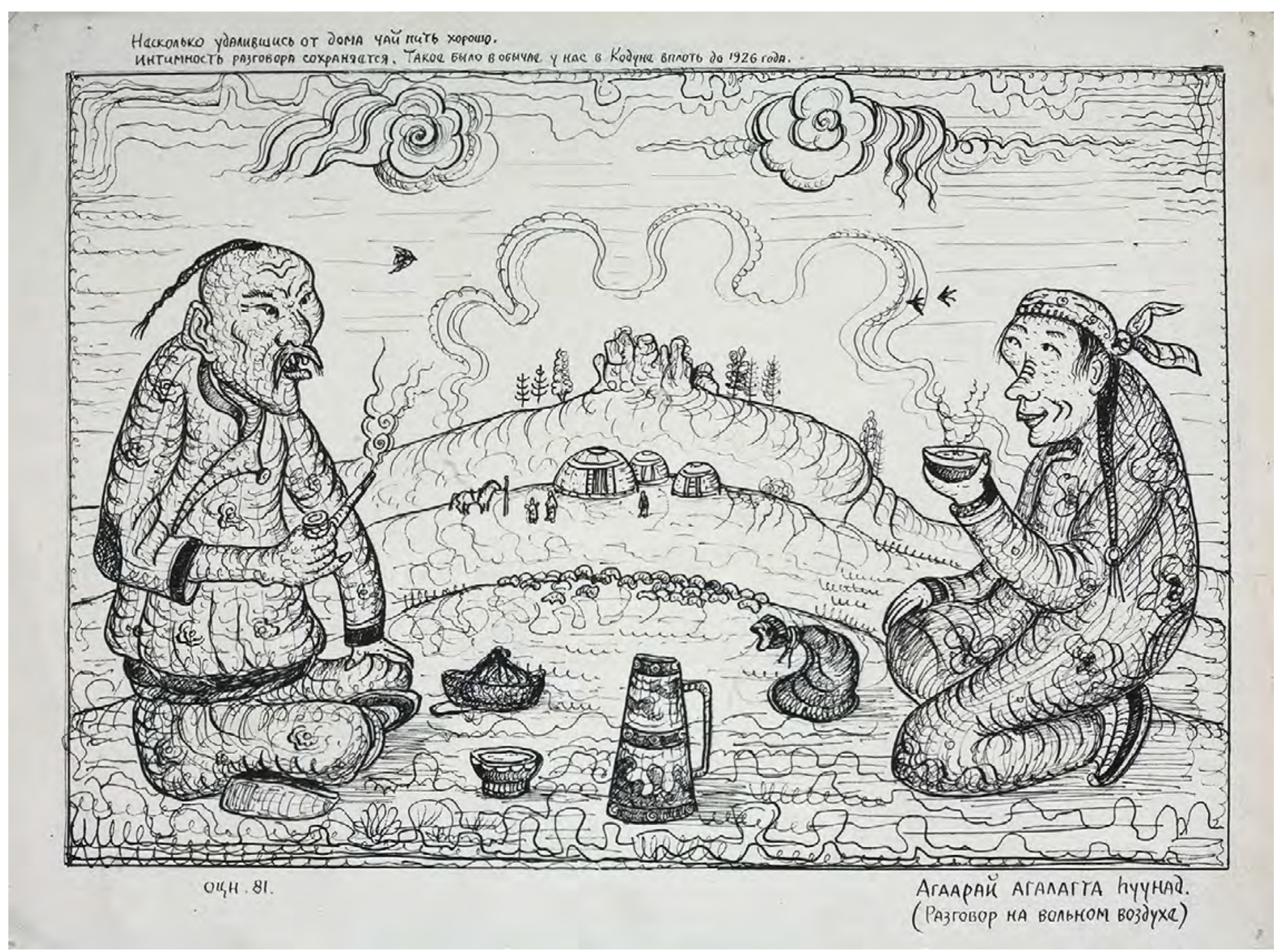

Цырен-Намжил Очиров, являясь носителем традиционной культуры бурят, прекрасно осознавал ее глубинные истоки. Как говорит З. Дугаров, «мир без пустот и полостей», здесь важен ритуал, и поэтому все композиции Очирова построены согласно ритуалу встречи - важны жесты, взгляды, позы героев. Как, например, в иллюстрациях к эпосу «Аламжи мэргэн» сюжет оживления главного героя царевной с помощью живой воды представлен подробно, в деталях (иллюстрация к эпосу «Аламжи мэргэн», лист 4-й, 1980; рис. 6).

Л.Ю. Николаева отмечает: «Человеку традиционной культуры мир представляется в образе Мирового Древа и состоит из трех частей (верхний, средний и нижний). Определяющие отношения складываются между срединным, земным миром, где пребывал сам человек и его предки, и небесным, где обитают покровители человека - Боги, создавшие мир» [11, с. 28]. Очиров создает свой мир, где человеку комфортно в природе, где горы и деревья, реки и озера, цветы и птицы - всё находится в гармонии. Мастер всегда предельно внимателен к деталям пейзажа: будь то полевые цветы, изображенные с точным знанием ботаники, или деревья с мощными корнями. Одновременно мы видим реалистичные виды его родного Могсохона («Перекочевка Боролдоя», 1980). Художник много ездит, внимательно наблюдает за природой и изображает именно тот пейзаж, который характерен для этого места. Взволнованность и непосредственность в восприятии мира, ощущение неразрывной связи человека и природы отличает практически каждый его лист. Рисунки Очирова словно втягивают зрителя вглубь традиционных житейских коллизий, в старинный фольклорный строй чувствований и переживаний. Повседневный быт людей окрашивается добрым и мягким юмором (таковы работы «Сбивание масла», «Катание войлока», «Игроки в шахматы», «Сбивание шерсти» и другие). Его произведения - это, в какой-то мере, тоска по «золотому веку», по старому, утраченному ныне патриархальному бурятскому быту. Отсюда, быть может, жадный интерес к фольклору, стремление запечатлеть собранный материал в рисунках [2, с. 96].

\section{5. Ц.-Н. Очиров.}

Разговор на вольном воздухе.

1981.

Бумага, тушь.

$36 \times 48$.

Национальный музей Республики Бурятия 
6. Ц.-Н. Очиров. Иллюстрация к эпосу

“Аламжи-Мэргэн». 1980.

Бумага, тушь.

$59 \times 83$.

Национальный музей Республики Бурятия

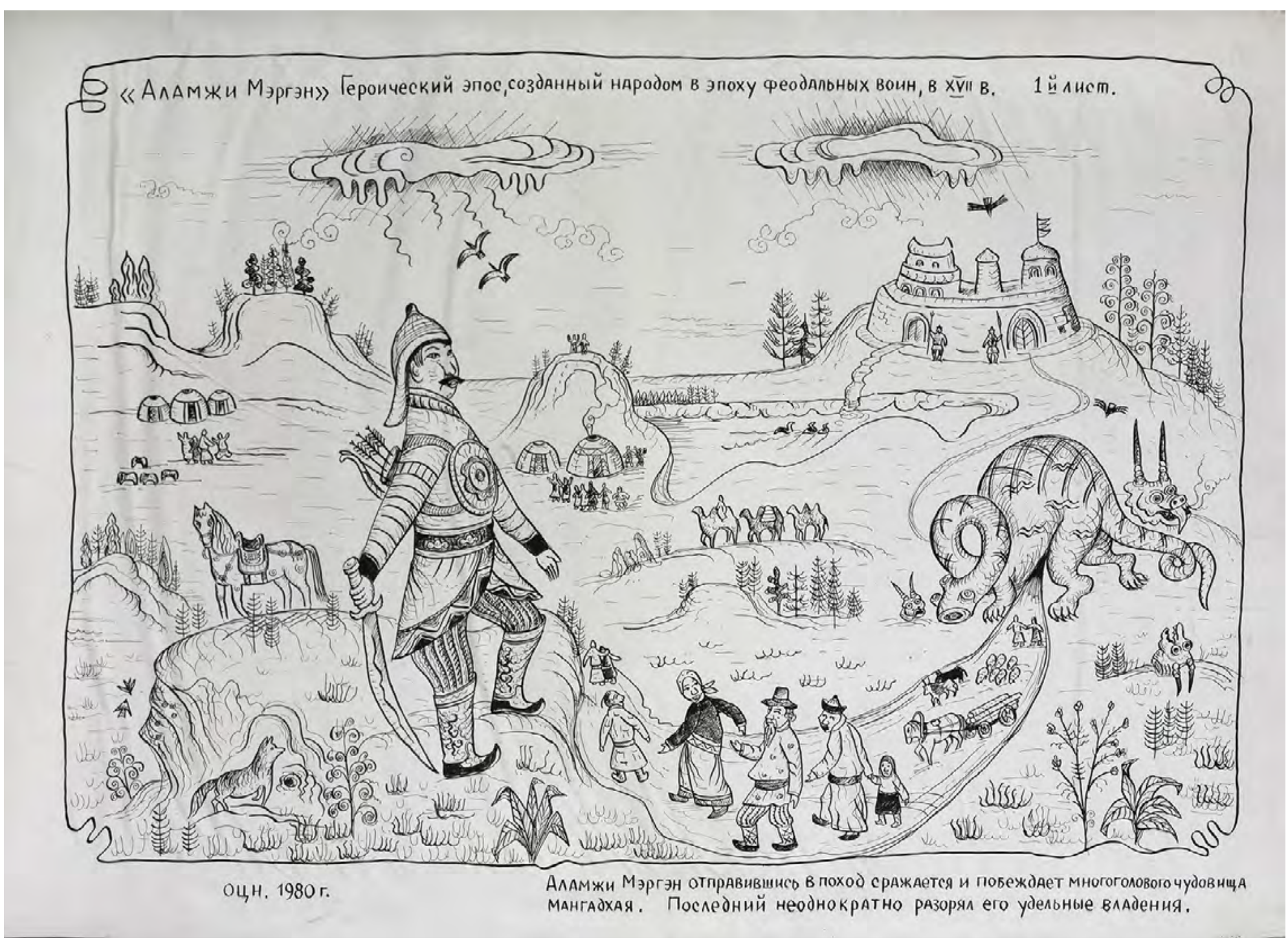

Мастер создает более 30 рукописных книг с короткими нравоучительными рассказами, записанными им со слов стариков и знатоков фольклора. Каждый рассказ сопровождается выразительной иллюстрацией (большая часть этих книг бережно хранится в семье художника, две из таких книг находятся в хранилище восточных рукописей Института монголоведения, буддологии и тибетологии CO PAH).

\section{Выводы}

Проведя анализ графического наследия Цырен-Намжила Очирова, можно сделать вывод о двух доминирующих истоках его творчества: 1) уникальная восточная графика, связанная с буддийским искусством; 2) народные фольклорные традиции и стиль «буряад зураг».

В связи с тем, что всё творческое наследие художника (около 500 работ) находится в разных городах и даже странах, возникла задача собрать в единый большой каталог и издать все рукописные книги автора.

Пожалуй, главное, что отличает работы Очирова, придает им печать самобытности, - это глубокая и неразрывная связь с традицией восточной графики. Творчество художника являет убедительный пример сохранения живой преемственности культур традиционного и современного общества. 


\title{
Искусство Евразии
}

\section{№1 (20) 2021 elSSN 2518-7767}

\author{
Литература
}

1. Бальжурова А.Ж. Буддийские мотивы в живописи Бурятии второй половины XX века // Вестник Челябинского государственного университета. 2014. № 10 (339). С. 154-156.

2. Бороноева Т.А. Грасика Бурятии. Улан-Удэ: Изд.-во БНЦ СО РАН, 1997. 127 с.

3. Выступление Зандана Дашинимаевича Дугарова, народного художника Республики Бурятия на круглом столе, посвященном международному бурятскому фестивалю «Алтаргана». Июль 2016 г. Личный архив Т.А. Бороноевой.

4. Герасимова К.М. К истории изобразительного искусства бурят // Записки БМНИИК. Улан-Удэ: Бурятское книжное издательство, 1956. Вып. 21. С. 106-116.

5. Запись беседы с дочерью художника Розой Цыреновной Очировой. 22 января 2021 г. Личный архив Т.А. Бороноевой.

6. Запись беседы с художником А. Москвитиным. Февраль 2021 г. Личный архив Т.А. Бороноевой.

7. Иофан Н.А., Цыбыктарова С.Д. Художник из Могсохона // Знание - Сила. 1990. № 1. С. 95-98.

8. Искусство народностей Сибири: Сборник статей / Государственный Русский музей. Ленинград: Государственный Русский музей, 1930. 107 с.

9. Николаева Л.Ю. Художественная система бурятского самодеятельного художника Цырен-Намжил Очирова (1920-1987) // Современное искусство Востока. Сборник материалов международной научной конференции / Ред-сост. Д. Н. Воробьева. М.: Московский музей современного искусства, Государственный институт искусствознания, 2017. С. $257-269$.

10. Очиров Ц.-Н. Будда и его жизнь. Могсохон: [б. и.], 1964. Рукописная книга. Личный архив дочери художника Р.Ц. Очировой. 11. Сибирский миф. Голоса территорий: живопись, графика, скульптура, декоративно-прикладное искусство художников Сибири XX-XXI веков: альбом-каталог / авт. ст. Л. Богомолова и др. Омск: Полиграф, 2008. 158 с.

12. Цырен-Намжил Очиров. Графика: альбом / Авт.-сост. С.Б. Тарнуева. Улан-Удэ: Нова Принт, 2019. 132 с.

ИНФОРМАЦИЯ ОБ АВТОРЕ: Бороноева Татьяна Анатольевна — кандидат искусствоведения, директор, Национальный музей Республики Бурятия, г. Улан-Удэ, Российская Федерация. Заслуженный деятель искусств Республики Бурятия, почетный член Российской академии художеств. E-mail: tatboronoeva@gmail.com

ABOUT AUTHOR: Boronoeva, Tatyana Anatolevna - Cand. Sc. (Art History), Director, the National museum of the Republic of Buryatia, Ulan-Ude, Russian Federation. Honorable member of the Russian Academy of Arts. E-mail: tatboronoeva@gmail.com 


\section{References}

1. Balzhurova A.Zh. Buddiiskie motivy v zhivopisi Buryatii vtoroi poloviny XX veka [Buddhist motives in the painting of Buryatia in the second half of the 20th century]. Vestnik Chelyabinskogo gosudarstvennogo universiteta - Bulletin of the Chelyabinsk State University, 2014, No. 10 (339), pp. 154-156. (In Russian).

2. Boronoeva T.A. Grafika Buryatii [Graphics of Buryatia]. Ulan-Ude, Buryat Scientific Center Siberian Branch of the Russian Academy of Sciences, 1997. 127 p. (In Russian).

3. Vystuplenie Zandana Dashinimaevicha Dugarova [Speech by Zandan Dashinimaevich Dugarov, People's Artist of the Republic of Buryatia, at a round table dedicated to the international Buryat festival Altargana. July, 2016. Personal archive of T.A. Boronoeva. (In Russian).

4. Gerasimova K.M. K istorii izobrazitel'nogo iskusstva buryat [On the history of the fine arts of the Buryats] Zapiski BMNIIK - Notes of Buryat-Mongolian Research Institute of Culture. Ulan-Ude, Buryatskoe knizhnoe izdatel'stvo Publ., 1956. Issue 21, pp. 106-116. (In Russian).

5. Recorded conversation with Rosa Tsyrenovna Ochirova. January 22, 2021. Personal archive of T.A. Boronoeva. (In Russian).

6. Recorded conversation with artist A. Moskvitin. February, 2021. Personal archive of T.A. Boronoeva. (In Russian).

7. Iofan N.A., Tsybyktarova S.D. Khudozhnik iz Mogsokhona [Artist from Mogsohon]. Znanie Sila - Knowledge is Power, 1990, No. 1, pp. 95-98. (In Russian).

8. Iskusstvo narodnostei Sibiri [Art of the peoples of Siberia: Collection of articles]. Leningrad, State Russian Museum, 1930.107 p. (In Russian).

9. Nikolaeva L.Yu. Khudozhestvennaya sistema buryatskogo samodeyatel'nogo khudozhnika Tsyren-Namzhil Ochirova (1920-1987) [The artistic system of the Buryat amateur artist Tsyren-Namzhil Ochirov (1920-1987)]. Vorobyova D.N. (ed.). Sovremennoe iskusstvo Vostoka [Contemporary Art of the East. Proceedings of conference]. Moscow, Moscow Museum of Modern Art, State Institute of Art Studies, 2017, pp. 257-269. (In Russian).

10. Ochirov Ts.-N. Budda i ego zhizn' [Buddha and his life]. Mogsohon, S. n., 1964. Handwritten book. Personal archive of R.Ts. Ochirova. (In Russian).

11. Bogomolova L. et al. Sibirskii mif. Golosa territorii [Siberian myth. Voices of the territories: painting, graphics, sculpture, arts and crafts of Siberian artists of the 20th - 21st centuries: album-catalog. Omsk, Polygraph, 2008. 158 p. (In Russian).

12. Tarnueva S.B. (comp.). Tsyren-Namzhil Ochirov. Grafika [Tsyren-Namzhil Ochirov. Graphics: album]. Ulan-Ude, Nova Print, 2019. 132 p. (In Russian).

\section{Для цитирования |For citation:}

Бороноева Т.А. Картина мира в графике бурятского художника Ц.-Н. Очирова // Искусство Евразии [Электронный журнал]. 2021. № 1 (20). C. 12-23. DOI: https://doi.org/10.46748/ARTEURAS.2021.01.001 URL: https://eurasia-art.ru/index.php/art/article/view/172

Boronoeva T.A. The picture of the world in the graphic art of the Buryat painter Tsyren-Namzhil Ochirov. Iskusstvo Evrazii The Art of Eurasia, 2021, No. 1 (20), pp. 12-23. DOl: https://doi.org/10.46748/ARTEURAS.2021.01.001 Available at: https://eurasia-art.ru/index.php/art/article/view/172 (In Russian). 